\title{
Reducing the Indoor Odorous Charge in Waste Treatment Facilities
}

\author{
E Gallego ${ }^{1 *}$, FJ Roca1, JF Perales ${ }^{1}$ and G Sánchez ${ }^{2}$
}

${ }^{1}$ Laboratory Centre for Environment, Polytechnic University of Catalonia (LCMA-UPC), Spain

${ }^{2}$ Department of Prevention and Waste Management of Greater Barcelona, Spain

\begin{abstract}
Characterising and determining the odorous charge of indoor air through Odour Units (OU) is an advantageous approach to evaluate indoor air quality and discomfort inside municipal solid waste facilities. The assessment of the OU can be done through the determination of Volatile Organic Compounds (VOC) concentrations and their odour thresholds. The aim of the study was to evaluate the differences in the odorous charge in the organic matter pit of a mechanical-biological waste treatment plant with a processing capacity of 287,500 tons year ${ }^{-1}$. The sampling was carried out during the months of September 2012 (original situation) and October 2012 (after emptying the organic matter pit drain pipe). 150 chemical compounds were determined qualitatively in the studied location, from which 102 were quantified due to their odorous characteristics as well as their potentiality of having negative health effects. The results obtained demonstrated that after a maintenance cleaning operation such as draining the organic matter pit pipe, the odorous charge inside the facility can be diminished in a great way, up to a $95 \%$.
\end{abstract}

Keywords: Indoor air quality; Maintenance cleaning; Municipal solid waste (MSW); Odour units; TD GC/MS; Volatile organic compounds (VOC)

\section{Introduction}

Perceptible malodours in the indoor air of waste treatment plants have a considerable impact on occupational comfort, hygiene, health and safety $[1,2]$. Volatile organic compounds (VOC) are the main causers of odorous nuisances [3], being formed and released to the indoor environment of waste treatment facilities either from degradation processes of the organic matter or by degradation and volatilization of other materials treated. Hence, determining the odorous contribution of each VOC or family to the total odorous charge in the indoor air is a helpful method to identify, characterize and evaluate the most annoying chemicals in order to prevent their generation during the waste treatment processes, as well as to find solutions to suppress them [3]. The working thesis assumes the superposition of the individual odorous concentrations calculated through VOC concentrations and their concrete odour thresholds $[3,4]$. It has to be taken into account that possible effects derived from masking or synergies between the evaluated compounds are not considered, and that the total odour units (OU) determined by olfactometry could differ in a certain way [5-8]. However, it has also to be considered that OU calculated using the presented methodology in a previous study were in the range of 1200-28,000 OU [3], in accordance with OU calculated using dynamic olfactometry $\left(5000-30,000 \mathrm{OU} \mathrm{m}^{-3}\right)$ in similar facilities $[9,10]$. Additionally, several studies have demonstrated good correlations between olfactometrically determined OU and VOC concentrations $[5,10,11]$. The use of the presented procedure is advisable to be used when comparing differences in the odorous charge when changes in the processes developed into the facility are implemented [3]. The aim of this short report is to exemplify the effects of maintenance cleaning operations, such as draining the organic matter pit pipe, in the odorous charge of indoor air in a waste treatment facility.

\section{Materials and Methods}

\section{Sampling strategy}

The evaluation of the odorous charge in two scenarios (before and after a cleaning maintenance operation, i.e. draining the organic matter pit pipe) was done in the organic matter pit building of a mechanical- biological waste treatment (MBT) plant located in the metropolitan area of Barcelona, which has a processing capacity of 287,500 tons year ${ }^{1}$ of municipal residues: selected organic fraction $\left(100,000\right.$ tons year $\left.{ }^{-1}\right)$, waste fraction $\left(160,000\right.$ tons year $\left.{ }^{-1}\right)$ and light packaging $(27,500$ tons year $\left.^{-1}\right)$. The selected organic matter fraction is discharged from the garbage trucks in a waste reception pit in a closed building. Organic matter is disposed in a conveyor belt by a bridge crane, led through a pre-treatment section, and eventually anaerobically digested to obtain biogas.

The organic matter pit building platform is cleaned twice a week according to a maintenance program consisting in the application of pressurized water. However, the organic matter pit pipeline is cleaned when lixiviates do not drain, without following a regular planification. Two samples from the organic matter pit indoor air were taken between $17^{\text {th }}$ and $25^{\text {th }}$ of September 2012 in the original conditions of the facility, without having emptied the lixiviate pipe of the pit for 2-3 weeks, respectively. Additionally, on the $1^{\text {st }}$ of October 2012 a sample was taken after 4 days of having purged the lixiviate pipeline. VOC and VSC were dynamically sampled by connecting custom packed glass multi-sorbent cartridge tubes (Carbotrap 20/40, 70 mg; Carbopack X 40/60, $100 \mathrm{mg}$ and Carboxen 569 20/45, $90 \mathrm{mg}$ ) and Tenax TA (60/80, $200 \mathrm{mg}$ ) tubes, respectively, to AirChek 2000 SKC pumps [12,13].

\section{Analytical instrumentation}

VOC and VSC were analysed by Automatic Thermal Desorption and capillary Gas Chromatography/Mass Spectrometry Detector using a Perkin Elmer ATD 400 (Perkin Elmer, Boston, Massachusetts, USA) and a Thermo Quest Trace 2000 GC (Thermo Quest, San Jose,

*Corresponding author: Eva Gallego, Laboratory Centre for Environment Polytechnic University of Catalonia (LCMA-UPC), Avda Diagonal 647, 08028 Barcelona, Spain, Tel: 34934016683; Fax: 34934017150; E-mail: Icma.info@upc.edu

Received December 05, 2013; Accepted February 12, 2014; Published February 19,2014

Citation: Gallego E, Roca FJ, Perales JF, Sánchez G (2014) Reducing the Indoor Odorous Charge in Waste Treatment Facilities. Int J Waste Resources 4: 136. doi: 10.4172/2252-5211.1000136

Copyright: $\odot 2014$ Gallego E, et al. This is an open-access article distributed under the terms of the Creative Commons Attribution License, which permits unrestricted use, distribution, and reproduction in any medium, provided the original author and source are credited. 
Citation: Gallego E, Roca FJ, Perales JF, Sánchez G (2014) Reducing the Indoor Odorous Charge in Waste Treatment Facilities. Int J Waste Resources 4: 136. doi: 10.4172/2252-5211.1000136

Page 2 of 5

California, USA) fitted with a Thermo Quest Trace Finnigan MSD. Mass spectral data were acquired over a mass range of 20-300 amu. Samples were quantified by the external standard method. The methodology is described elsewhere [12].

Limits of detection, determined with a signal-to-noise ratio of 3 , ranged from 0.001 to $10 \mathrm{ng}$. Compounds showed repeatabilities (\% relative standard deviation values) $\leq 25 \%$.

\section{Results and Discussion}

\section{Indoor air VOC concentrations}

150 chemical compounds were determined qualitatively in the studied location, as it had been observed in a previous study [3], from which 102 were quantified (those compounds with a low odour threshold as well as those with toxicity component or potential negative health effects). Table 1 shows the chemical familial concentrations for each sampling day. Concentrations obtained were of the same order of magnitude than the observed in previous studies regarding organic matter waste treatment, being terpenoids, alcohols, carboxylic acids and esters the mainly emitted compounds $[3,6,14]$. Generally, familial concentrations increase from $23-282 \%$, with a global value of $45 \%$ between the two first samplings. Four days after cleaning, concentrations decreased a global value of $70 \%$ in respect to the sample taken 3 weeks after the last pipeline drainage (25th September). Terpenoid and aldehyde concentrations did not vary in a substantial way after the pipeline drainage process.

In the original scenario, alcohols, terpenoids, carboxylic acids, esters and ketones showed higher concentrations in respect to the other families evaluated, as observed in a previous study [3]. However, when the pipeline was drained, the most concentrated VOC were alcohols, terpenoids, ketones and aldehydes.

VOC concentrations did not exceed the VLA-ED (Table 2), the Spanish correspondence for Threshold Limit Value (TLV)-Time Weighted Average, as it had been observed in previous studies conducted in similar facilities $[3,10,15]$. However, as a great number

\begin{tabular}{|c|c|c|c|c|c|}
\hline \multirow{2}{*}{ Family } & \multirow{2}{*}{$\begin{array}{c}17^{\text {th }} \text { September } \\
\mu \mathrm{g} \mathrm{m}^{-3}\end{array}$} & \multicolumn{2}{|c|}{$25^{\text {th }}$ September } & \multicolumn{2}{|c|}{$1^{\text {st }}$ October } \\
\hline & & $\mu \mathrm{g} \mathrm{m}^{-3}$ & Increase (\%) $)^{a}$ & $\mu \mathrm{g} \mathrm{m}^{-3}$ & Decrease $(\%)^{\mathrm{b}}$ \\
\hline Alkanes & 218 & 380 & 74 & 9.4 & 98 \\
\hline Aromatic hydrocarbons & 551 & 761 & 38 & 47 & 94 \\
\hline Alcohols & 91,161 & 124,464 & 37 & 21,129 & 83 \\
\hline Ketones & 2854 & 4657 & 63 & 1064 & 77 \\
\hline Halocarbons & 137 & 45 & $-67^{\circ}$ & 11 & 76 \\
\hline Aldehydes & 290 & 795 & 174 & 802 & $-1^{d}$ \\
\hline Esters & 2984 & 3664 & 23 & 178 & 95 \\
\hline Acids & 3250 & 9884 & 204 & 163 & 98 \\
\hline Terpenoids & 15,896 & 24,953 & 57 & 27,339 & $-10^{d}$ \\
\hline Organosulfurs & 165 & 219 & 33 & 10 & 95 \\
\hline Ethers & 1.7 & 6.5 & 282 & 5.7 & 12 \\
\hline Furans & 4.5 & 6.2 & 38 & 0.2 & 97 \\
\hline Glycols & 123 & 155 & 26 & 7.0 & 95 \\
\hline Organonitrogenated & 5.5 & 3.3 & $-40^{c}$ & 1.0 & 70 \\
\hline Total VOC $\left(\mathrm{mg} \mathrm{m}^{-3}\right)$ & 118 & 170 & 45 & 51 & 70 \\
\hline
\end{tabular}

alncrease in concentrations (\%) from $17^{\text {th }}$ September to $25^{\text {th }}$ September

becrease in concentrations (\%) from $25^{\text {th }}$ September to $1^{\text {st }}$ October

'Decrease in concentrations.

dncrease in concentrations.

Table 1: Indoor familial concentrations $\left(\mu \mathrm{g} \mathrm{m}^{-3}\right)$ in the organic matter pit.

\begin{tabular}{|c|c|c|c|c|c|c|}
\hline Compound & $17^{\text {th }}$ September & $25^{\text {th }}$ September & $1^{\text {st }}$ October & Odour threshold ${ }^{a}$ & VLA-ED & Vapour pressure $^{c}$ \\
\hline \multicolumn{7}{|c|}{ Aromatic hydrocarbons } \\
\hline$m+p$-Ethyltoluene & 28.1 & 72.0 & 1.1 & 42 & $--^{d}$ & 0.4 \\
\hline Styrene & 14.0 & 32.2 & 0.3 & 12 & 86,000 & 0.6 \\
\hline \multicolumn{7}{|l|}{ Alcohols } \\
\hline 1-Butanol & 382 & 2521 & 31.6 & 480 & 61,000 & 0.9 \\
\hline 1-Hexanol & 28.7 & 56.0 & 1.1 & 40 & - & 0.1 \\
\hline 1-Propanol & 1733 & 4042 & 69.1 & 2000 & 246,000 & 3.5 \\
\hline 2-Butanol & 5161 & 7619 & 183 & 400 & 308,000 & 2.4 \\
\hline Ethanol & 82,397 & 106,833 & 20,547 & 2000 & $1,910,000^{e}$ & 7.9 \\
\hline \multicolumn{7}{|l|}{ Ketones } \\
\hline Biacetyl & 32.8 & 162 & 1.7 & 0.7 & - & 7.6 \\
\hline \multicolumn{7}{|l|}{ Aldehydes } \\
\hline Acetaldehyde & 221 & 651 & 786 & 2.7 & $46,000^{e}$ & 120 \\
\hline Benzaldehyde & 9.9 & 26.1 & 4.2 & 10 & - & 0.1 \\
\hline Isovaleraldehyde & 2.6 & 3.3 & 0.3 & 1.6 & - & 6.6 \\
\hline Propanal & 24.3 & 58.9 & 4.5 & 3.6 & $48,300^{f}$ & 39.9 \\
\hline \multicolumn{7}{|l|}{ Esters } \\
\hline Ethyl butyrate & 38.8 & 113 & 0.6 & 0.017 & - & 1.7 \\
\hline
\end{tabular}


Citation: Gallego E, Roca FJ, Perales JF, Sánchez G (2014) Reducing the Indoor Odorous Charge in Waste Treatment Facilities. Int J Waste Resources 4: 136. doi: 10.4172/2252-5211.1000136

Page 3 of 5

\begin{tabular}{|c|c|c|c|c|c|c|}
\hline Ethyl hexanoate & 74.2 & 255 & 1.7 & 10 & - & 0.2 \\
\hline Ethyl isovalerate & 0.8 & 2.2 & 0.04 & 0.1 & - & 1.1 \\
\hline Ethyl octanoate & 2.8 & 13.4 & 0.2 & 6 & - & 0.03 \\
\hline Methyl butyrate & 5.5 & 9.6 & 0.1 & 7.7 & - & 4.2 \\
\hline \multicolumn{7}{|l|}{ Acids } \\
\hline Acetic acid & 572 & 4070 & 95 & 90 & 25,000 & 2.1 \\
\hline Butanoic acid & 16.0 & 365 & 1.8 & 0.35 & - & 0.2 \\
\hline Hexanoic acid & 2653 & 5245 & 59.5 & 20 & - & 0.02 \\
\hline Propanoic acid & 7.2 & 194 & 6.8 & 5.1 & 31,000 & 0.6 \\
\hline \multicolumn{7}{|l|}{ Terpenoids } \\
\hline D-Limonene & 14,600 & 22,851 & 15,798 & 1700 & $110,000^{f}$ & 0.3 \\
\hline p-Cymene & 640 & 726 & 11,457 & 200 & - & 0.2 \\
\hline a-Pinene & 191 & 277 & 14.6 & 230 & 113,000 & 0.6 \\
\hline$\beta$-Myrcene & 78.9 & 164 & 10.2 & 130 & - & 0.3 \\
\hline \multicolumn{7}{|l|}{ Organosulfurs } \\
\hline Dimethyl disulfide & 151 & 187 & 5.1 & 7 & - & 3.8 \\
\hline Dimethyl sulfide & 13.3 & 24.2 & 0.3 & 1 & 25,800 & 86.3 \\
\hline
\end{tabular}

aSource: "Compilations of odourthres hold values in air and water", L.J. van Gemert (TNO Nutrition and Food Research Institute). Boelens Aroma Chemicals InformationService (BACIS). The Netherlands (2003); "OdorThresholds for Chemicals with Established Occupational Health Standards" American Industrial Hygiene Association.USA (2009);

"Reference Guide to Odor Thresholds for Hazardous Air Pollutants Listed in the Clean Air Act Amendments of 1990". EPA/600/R-92/047 (2009); and "Measurement of odor threshold by triangle odor bag method", Y. Nagata.Odor Measurement Review, 118-127, Japan Ministry of Environment (2003).

bValor Límite Ambiental-Exposición Diaria: the Spanish correspondence for Threshold Limit Value-Time Weighted Average (TLV-TWA).

'Vapour pressure at $25^{\circ} \mathrm{C}(\mathrm{kPa})$

'Not established value

eAs VLA-EC: Valor Límite Ambiental-Exposición de cortaduración (maximum of 15 min during the daily exposure)

fProposed value

Table 2: Concentrations $\left(\mu \mathrm{g} \mathrm{m}^{-3}\right)$ of selected relevant odorous VOC in the organic matter pit. Concentrations with grey shading exceed the odour threshold of the compound.

\begin{tabular}{|c|c|c|c|c|c|}
\hline \multirow{2}{*}{ Compound } & \multirow{2}{*}{$\begin{array}{c}17^{\text {th }} \text { September } \\
\text { OU }\end{array}$} & \multicolumn{2}{|c|}{$25^{\text {th }}$ September } & \multicolumn{2}{|c|}{$1^{\text {st }}$ October } \\
\hline & & OU & Increase $(\%)^{a}$ & OU & Decrease $(\%)^{b}$ \\
\hline \multicolumn{6}{|l|}{ Aromatic hydrocarbons } \\
\hline$m+p-E$ thyltoluene & $<1^{c}$ & 1.7 & $-{ }^{d}$ & $<1$ & 100 \\
\hline Styrene & 1.2 & 2.7 & 125 & $<1$ & 100 \\
\hline Total OU Aromatic hydrocarbons & 1.2 & 4.4 & 267 & $<1$ & 100 \\
\hline \multicolumn{6}{|l|}{ Alcohols } \\
\hline 1-Butanol & $<1$ & 5.3 & - & $<1$ & 100 \\
\hline 1-Hexanol & $<1$ & 1.4 & - & $<1$ & 100 \\
\hline 1-Propanol & $<1$ & 2.0 & - & $<1$ & 100 \\
\hline 2-Butanol & 13 & 19 & 46 & $<1$ & 100 \\
\hline Ethanol & 41 & 53 & 29 & 10 & 81 \\
\hline Total OU Alcohols & 54 & 81 & 50 & 10 & 88 \\
\hline \multicolumn{6}{|l|}{ Ketones } \\
\hline Biacetyl & 47 & 232 & 394 & 2.4 & 99 \\
\hline Total OU Ketones & 47 & 232 & 394 & 2 & 99 \\
\hline \multicolumn{6}{|l|}{ Aldehydes } \\
\hline Acetaldehyde & 82 & 241 & 194 & 291 & $-21^{e}$ \\
\hline Benzaldehyde & $<1$ & 2.6 & - & $<1$ & 100 \\
\hline Isovaleraldehyde & 1.6 & 2.1 & 31 & $<1$ & 100 \\
\hline Propanal & 6.7 & 16 & 139 & 1.3 & 91 \\
\hline Total OU Aldehydes & 90 & 262 & 191 & 292 & $-11^{e}$ \\
\hline \multicolumn{6}{|l|}{ Esters } \\
\hline Ethyl butyrate & 2284 & 6654 & 191 & 34 & 99 \\
\hline Ethyl hexanoate & 7.4 & 25 & 238 & $<1$ & 100 \\
\hline Ethyl isovalerate & 7.6 & 22 & 189 & $<1$ & 100 \\
\hline Ethyl octanoate & $<1$ & 2.2 & - & $<1$ & 100 \\
\hline Methyl butyrate & $<1$ & 1.2 & - & $<1$ & 100 \\
\hline Total OU Esters & 2299 & 6704 & 192 & 34 & 99 \\
\hline \multicolumn{6}{|l|}{ Acids } \\
\hline Acetic acid & 6.4 & 45 & 603 & 1.1 & 98 \\
\hline Butanoic acid & 46 & 1041 & 2163 & 5.1 & 99 \\
\hline Hexanoic acid & 133 & 262 & 97 & 3.0 & 99 \\
\hline Propanoic acid & 1.4 & 38 & 2614 & 1.3 & 97 \\
\hline
\end{tabular}




\begin{tabular}{|c|c|c|c|c|c|}
\hline Toal OU Acids & 186 & 1387 & 646 & 10 & 99 \\
\hline \multicolumn{6}{|l|}{ Terpenoids } \\
\hline D-Limonene & 8.6 & 13 & 51 & 9.3 & 28 \\
\hline p-Cymene & 3.2 & 3.6 & 13 & 57 & $-1483^{e}$ \\
\hline a-Pinene & $<1$ & 1.2 & - & $<1$ & 100 \\
\hline$\beta$-Myrcene & $<1$ & 1.3 & - & $<1$ & 100 \\
\hline Total OU Terpenoids & 12 & 20 & 67 & 66 & $-230^{e}$ \\
\hline \multicolumn{6}{|l|}{ Organosulfurs } \\
\hline Dimethyl disulfide & 22 & 27 & 23 & $<1$ & 100 \\
\hline Dimethyl sulfide & 13 & 24 & 85 & $<1$ & 100 \\
\hline Total OU Organosulfurs & 35 & 51 & 46 & $<1$ & 100 \\
\hline Total OU & 2724 & 8741 & 221 & 414 & 95 \\
\hline
\end{tabular}

ancrease in OU (\%) from 17 th September to 25 th September

bDecrease in OU (\%) from 25th September to 1st October

${ }^{\circ}$ Concentration of the compound below the odour threshold, hence, odour units below the unity.

dincrease not calculated due to the absence of OU from this compound the 17 th September.

eIncrease in $\mathrm{OU}$

Table 3: Odour units $(\mathrm{OU})$ in the organic matter pit.

of VOC exceed their odour thresholds, they can lead to a lower employee satisfaction and productivity in the workplace, as well as to an increase of discomfort and personnel health hazards [1517]. High VOC concentrations, even presenting lower values than TLV, can cause direct reactions such as sensory irritation of mucous membranes (eyes, nose and throat), and other individual's subjective symptoms like weakness, confusion, difficulty in making decisions, headache and memory loss $[2,18]$. In a previous study conducted in the same facility evaluated in the present paper, the total carcinogenic and non-carcinogenic risks (sum of selected VOC) were obtained in the ranges of $10^{-5}-10^{-4}$ and $10^{-2}-6$, respectively [15]. Even though, long term epidemiological occupational health studies in municipal waste management plants are scarce. Additionally, major differences exist among developed and developing countries in relation to health and safety management in this kind of facilities. More research in this field has to be promoted before long, and the use of biomarkers can be a crucial step in order to detect biological effects in the exposed workers before the illnesses are diagnosed [1].

\section{Odorous charge}

The OU, calculated by dividing the concentration of a specific compound by its odour threshold limit, indicate how many times the threshold limit has been exceeded [3]. The OU in the organic matter pit are presented in Table 3. Familial OU increase from 46 to $646 \%$, with a global value of $221 \%$ between the two first samplings, a higher increase than in concentrations, mainly due to the low odour thresholds that present several compounds. Additionally, some compounds only generate OU on the $25^{\text {th }}$ of September, when their concentrations are relatively high (e.g. certain alcohols, aldehydes, esters and terpenes). These compounds present odour thresholds between 6 and 2000 $\mu \mathrm{gm}^{-3}$. The above mentioned compounds present the lower vapour pressures, between $0.03-4.2 \mathrm{kPa}$ at $25^{\circ} \mathrm{C}$, being less volatile than the other evaluated compounds, and only present in concentrations that generate $\mathrm{OU}$ when their accumulation due to lack of cleaning is produced. Carboxylic acids, $p$-cymene and $\alpha$-pinene also present similar vapour pressures, yet they are the main released compounds from organic matter degradation processes $[3,19]$. Once the pipeline was drained, $\mathrm{OU}$ in the organic matter pit decreased a global value of $95 \%$. Previously to the draining process, esters were the family that contributed most to total OU (Figure 1), as already observed in a preceding study [3]. After the pipe was drained, ketones, esters, carboxylic acids and organosulfurs decreased in a relevant way their

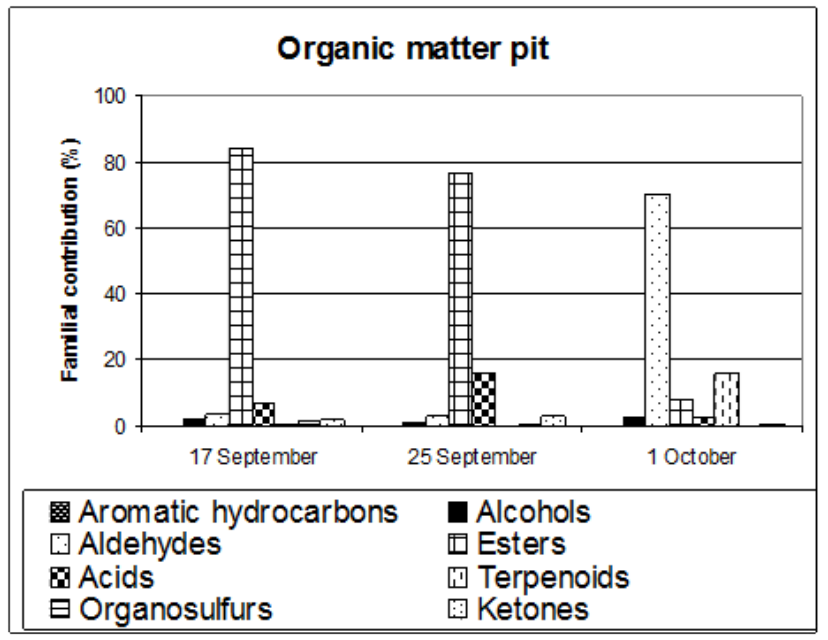

Figure 1 : Odourunits $(\mathrm{OU})$ familial distribution. Percentage of $\mathrm{OU}$ of each family in respect to all OU determined.

contribution to the total OU. Hence, the main contributors to total OU in this second scenario were aldehydes and terpenoids.

\section{Conclusions}

The best way to avoid the nuisance produced by odours in a waste treatment plant is not generating them, reducing at a minimum the presence of VOC in the indoor air of the facility. The present study has demonstrated that with a simple maintenance operation odours can be reduced up to $95 \%$. Programming a purging procedure instead of purging when the pipeline lixiviates do not drain would decrease indoor discomfort related to odours. This work is a preliminary approach to the effects of cleaning maintenance programs in respect to ambient VOC. Deeper evaluations and more research are needed in this field.

\section{Acknowledgements}

The authors acknowledge the support given through the EHMAN project (DPI2009-09386) financed both for the Spanish Ministry of Science and Innovation and the ERDF from the EU. E.G. acknowledges with thanks a Juan de la Cierva grant from the Spanish Ministry of Science and Innovation. 
Citation: Gallego E, Roca FJ, Perales JF, Sánchez G (2014) Reducing the Indoor Odorous Charge in Waste Treatment Facilities. Int J Waste Resources 4: 136. doi: 10.4172/2252-5211.1000136

Page 5 of 5

\section{References}

1. Giusti $L$ (2009) A review of waste management practices and their impact on human health. Waste Manag 29: 2227-2239.

2. Lehtinen J, Tolvanen O, Nivukoski U, Veijanen A, Hanninen K (2013) Occupational hygiene in terms of volatile organic compounds (VOCs) and bioaerosols at two solid waste management plants in Finland. Waste Manag 33: 964-973.

3. Gallego E, Roca FJ, Perales JF, Sanchez G, Esplugas P (2012) Characterization and determination of the odorous charge in the indoor air of a waste treatment facility through the evaluation of volatile organic compounds (VOCs) using TD-GC/MS. Waste Manag 32: 2469-2481.

4. Schauberger G, Piringer M, Knauder W, Petz E (2011) Odour emissions from a waste treatment plant using an inverse dispersion technique. Atmospheric Environment 45: 1639-1647.

5. Tsai CJ, Chen ML, YeAD, Chou MS, Shen SH, et al. (2008) The relationship of odor concentration and the critical components emitted from food waste composting plants. Atmospheric Environment 42: 8246-8251.

6. Orzi V, Cadena E, D'Imporzano G, Artola A, Davoli E, et al. (2010) Potentia odour emission measurement in organic fraction of municipal solid waste during anaerobic digestion: Relationship with process and biological stability parameters. Bioresource Technology 101: 7330-7337.

7. Almarcha D, Almarcha M, Nadal S, Caixach J (2012) Comparison of the depuration efficiency for VOC and other odoriferous compounds in conventional and advanced biofilters in the abatement of odour emissions from municipal waste treatment plants. Chemical Engineering Transactions 30: 259-264.

8. Dorado AD, Husni S, Pascual G, Puigdellivol C, Gabriel D (2014) Inventory and treatment of compost maturation emissions in a municipal solid waste treatment facility. Waste Manag 34: 344-351.

9. Schlegelmilch M, Streese J, Biedermann W, Herold T, Stegmann R (2005) Odour control at biowaste composting facilities. Waste Manag 25: 917-927.

10. Scaglia B, Orzi V, Artola A, Font X, Davoli E, et al. (2011) Odours and volatile organic compounds emitted from municipal solid waste at different stage of decomposition and relationship with biological stability. Bioresource Technology 102: $4638-4645$

11. Pierucci P, Porazzi E, Pardo MM., Adani F, Carati C, et al. (2005) Volatile organic compounds produced during the aerobic biological processing of municipal solid waste in a pilot plant. Chemosphere 59: 423-430.

12. Ribes A, Carrera G, Gallego E, Roca X, Berenguer MJX (2007) Development and validation of a method for air-quality and nuisance odors monitoring of volatile organic compounds using multi-sorbent adsorption and gas chromatography/mass spectrometry thermal desorption system. J Chromatogr A 1140: 44-55.

13. Gallego E, Roca FX, Perales JF, Rosell MG, Guardino X (2008) Development and validation of a method for air-quality and nuisance odours monitoring of volatile sulphur compounds (VSCs) using ATD-GC/MS. Proceedings of the 12th Day of Instrumental Analysis, 21-23 October, Barcelona.

14. Leguizamón DS (2003) The Air Qualityclosed a plant for the treatment and recovery of the organic fraction of municipal solidwaste. Spain.

15. Nadal M, Inza I, Schumacher M, Figueras MJ, Domingo JL (2009) Health risks of the occupational exposure to microbiological and chemical pollutants in a municipal waste organic fraction treatment plant. IntJ Hyg Environ Health 212 661-669.

16. Harrison EZ (2007) Health impacts of composting air emissions. Biocycle 48 44-50.

17. Domingo JL, Nadal M (2009) Domestic waste composting facilities: A review of human health risks. Environ Int 35: 382-389.

18. Smeets MAM, Dalton PH (2005) Evaluating the human response to chemicals: odor, irritation and non-sensory factors. Environ Toxicol Pharmaco I19: 581-588.

19. Staley BF, Xu F, Cowie SJ, Barlaz MA, Hater GR (2006) Release of trace organic compounds during the decomposition of municipal solid waste components. Environ Sci Technol 40: 5984-5991. 